\title{
Influence of grazing management and drought on white clover population performance and genotypic frequency
}

\author{
J.L. BROCK and J.R. CARADUS \\ AgResearch Grasslands, Private Bag 11008, Palmerston North, New Zealand
}

\begin{abstract}
Between 1984 and 1990, the performance of 'Tahora', 'Huia', 'Pitau' and 'Kopu' white clover cultivars were evaluated in self-contained farmlets under rotational grazing and set stocking with sheep. A severe late spring-early summer drought in the third year from sowing (1986-87), caused a marked interaction between grazing management and cultivar performance. The drought caused no losses under set stocking, but large losses of stolon $(75-90 \%)$ and a reduction in white clover content from $15 \%$ to $2 \%$ under rotational grazing. All cultivars were equally affected and recovery over the next 3 years was slow, although the small-leaved Tahora recovered faster than the large-leaved Pitau and Kopu. It was hypothesised that this would have caused differences in the preferential loss of genotypes with specific characteristics between grazing managements. Populations of white clover sampled from the field in 1989 and established from the original seedlines, were grown in common conditions for a year and compared for leaf size and cyanogenesis content. There had been a significant loss in mean leaf size in all cultivars with time, irrespective of drought or grazing management. It was shown that a general decline in stolon biomass commenced in all treatments 18 months after sowing, suggesting either, (1) a preferential loss of large-leaved genotypes with time irrespective of grazing management, or (2), a general change in per-formance of all genotypes, which may coincide with the change from dependence on seminal taproot of the seedling, to nodal rooting on free growing stolons.
\end{abstract}

Keywords: cultivars, drought, genotypic change, grazing management, populations, Trifolium repens, white clover

\section{Introduction}

During an experiment evaluating the performance of four white clover (Trifolium repens) cultivars in mixed pastures under grazing (Brock 1988), it was found that grazing management interacted dramatically with severe drought in the early summer of the third year. White clover populations were severely depleted in rotationally grazed systems but were not affected under set stocking, irrespective of white clover cultivar. It is hypothesised that as a consequence, this may have caused a preferential loss of genotypes (from all cultivars) between grazing managements. This paper follows the recovery of the cultivars over the following three years, and compares the mean genotypic structure of white clover populations at sowing and three years after the drought.

\section{Methods and materials}

In autumn 1984, new pastures were sown with $16 \mathrm{~kg} / \mathrm{ha}$ of high endophyte perennial ryegrass (Grasslands Nui and Grasslands Ariki in equal proportions) and $3 \mathrm{~kg} / \mathrm{ha}$ white clover in equal sub-plots of Grasslands Tahora, Grasslands Huia, Grasslands Pitau or Grasslands Kopu. These formed part of a larger grazing management experiment established as self-contained farmlets in 1978. Each farmlet was either rotationally grazed (12 paddocks) or continuously set stocked all year, and stocked at 22.5 ewes and lambs/ha. Grazing rotation lengths varied from 24 days in spring, to 36 days in summer-autumn, to 60 days in winter. For the first year, all pastures were established under periodic on/off grazing, and normal farmlet grazing management commenced in April 1985.

White clover performance was monitored in all treatments for 4.5 years at 4 to 8 weekly intervals (depending on time of year) by (1), cutting $0.36 \mathrm{~m}^{2}$ quadrats to ground level with an electric shearing handpiece for herbage yield and botanical dissection into sown species, and (2), taking 50mm diameter pasture cores to estimate population characteristics (leaf area and DW, stolon density (growing points) and DW). Samples from rotationally grazed pastures were taken immediately before grazing so that maximum expression of growth characteristics was recorded. Climate data was collected from an official meteorological station $300 \mathrm{~m}$ from the experimental site.

In order to determine any genetic change in the white clover population during the experimental period, 40 genotypes were collected at random from each cultivar by grazing management treatment in spring of 1989 . These genotypes, plus 40 randomly selected genotypes germinated from seed of the original seedlines sown, were established in $12 \mathrm{~cm}$ plastic potting bags, and maintained outside under uniform conditions and regular 
cutting to remove any cultural influence on plant growth characteristics. After a full year, width of the middle leaflet and cyanogenesis (picrate test) of the youngest fully expanded leaf of all plants were assessed.

\section{Results and discussion}

\section{Climate and white cloverperformance}

Climate conditions were near average during the establishment year (1984-85). The first two years under grazing treatment were contrasted, as year 1 (1985-86) had an unusually wet summer $(+60 \%$ rainfall), whereas year 2 (1986-87) had a severe drought in late springearly summer (-40\% rainfall, November to mid January) which completely disrupted the normal recovery pattern following plant fragmentation in mid-spring (Brock et al. 1988). The drought had a major impact on the subsequent performance of white clover under rotational grazing. White clover content of these pastures fell from $\mathbf{1 5 \%}$ in early spring to $2 \%$ in summer (Figure 1 ). Stolon DW decreased by 75-90\%, Recovery was slow, taking two years for growing point density, while stolon DW never regained pre-drought values. Under set stocking, white clover suffered only a temporary loss of leaf from wilting during the height of the drought, from which there was a rapid recovery. Stolon DW and growing point density were not influenced by the drought.

Figure 1: White clover performance in mixed pastures expressed as changes in (a), \% contribution to herbage yield, and (b) stolon biomass, over 4 years under rotational grazing (-) or set stocking (-----) by sheep at Palmerston North (sown autumn 1984).

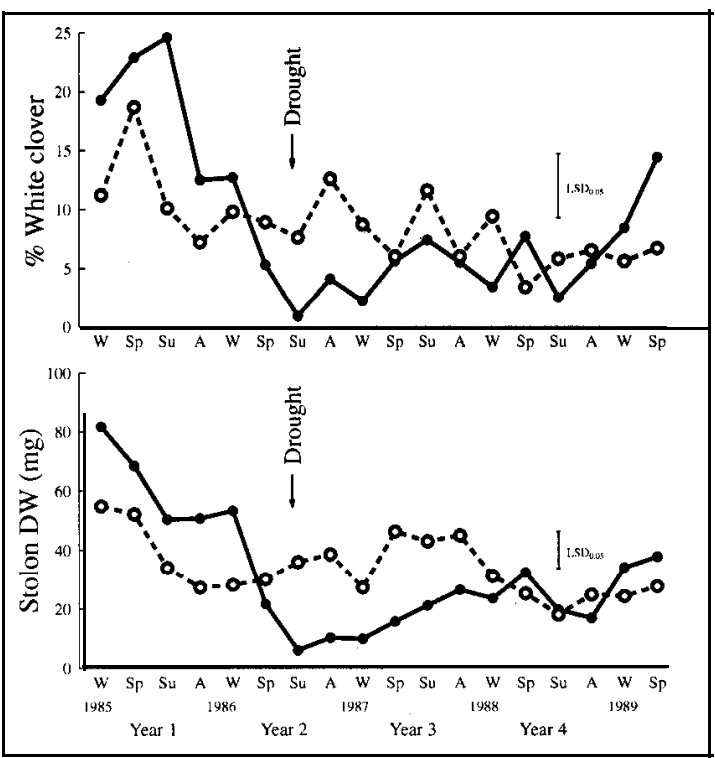

The differential loss of stolon between grazing managements was attributed to an interaction of pasture density, particularly the grass component, and soil surface temperature. The high density set stocked pastures, shaded white clover stolons, protecting them from direct solar radiation and also lowered soil surface temperature. However, in the open, low density rotationally grazed pastures, there was little protection from direct solar radiation, and soil surface temperatures and stolon death were higher. Soil surface temperature differentials of $8^{\circ} \mathrm{C}$ between grazing managements have been reported (rotationally grazed $48^{\circ} \mathrm{C}$, set stocked $40^{\circ} \mathrm{C}$; Brock \& Hay 1993). Further experiments confirmed the beneficial effects of soil shading on white clover survival, and also showed that a higher density of nodes was of greater significance for survival than the size of plants or stolons or root characteristics (Brock $\&$ Kim 1994).

\section{Cultivar comparison}

There was a clear interaction between cultivar and grazing management in year 1 under grazing treatment (1985-86) (Table 1). Under rotational grazing, all cultivars performed well with the greatest advantage to Kopu due to a combination of a large area/leaf and high leaf:stolon ratio (Tahora 0.91, Huia 1.06, Pitau 1.16, Kopu 1.36). Under set stocking, the higher frequency of defoliation favoured cultivars capable of greater development of growing point density (e.g., Tahora). Many plants in the large-leaved cultivars were unable to survive such changes and the population declined. This pattern was maintained throughout the experiment.

The advent of the drought in year 2 (1986-87) eliminated any differences in cultivar ranking's under rotational grazing (Table 1). Immediate loss of stolon (and growing points) ranged from $75 \%$ for Tahora and Huia, to $90 \%$ for Pitau and Kopu, with more rapid recovery in Tahora (50\% of pre-drought values) than Kopu (15\% of pre-drought values), with Huia and Pitau similar and intermediate (Brock 1988). By 1990, Tahora was still the best performing cultivar. Subsequent research by Brock and Kim (1994) confirmed that recovery of Tahora from drought is faster, due to a higher number of nodes surviving and quicker initiation of roots and new shoots, as compared to a large-leaved cultivar, Dusi.

Under set stocking, the drought in year 2 had little effect, and in fact, Tahora increased in stolon DW and growing point density (Brock 1988).

\section{Change in mean population characteristics}

The interaction of grazing management and drought on stolon death, suggested that natural selection may have occurred within the rotationally grazed populations. The 
Table 1: Change in contribution to yield, mean area/leaf and stolon thickness of white clover cultivars over 5 years under rotational grazing or set stocking (1986-87 severe drought).

\begin{tabular}{|c|c|c|c|c|c|c|c|c|c|}
\hline \multirow[t]{2}{*}{ Character } & \multirow[t]{2}{*}{ Year } & \multicolumn{4}{|c|}{ Rotationagrazing-_.............. } & \multicolumn{4}{|c|}{ 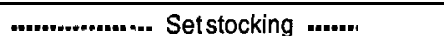 } \\
\hline & & Tahora & Huia & Pitau & Kopu & Tahora & Huia & Pitau & Kopu \\
\hline Content in pasture (\%) & $\begin{array}{l}1985-86 \\
1986-87 \\
1989-90\end{array}$ & $\begin{array}{c}20.1 \mathrm{a}^{*} \\
3.8 \mathrm{~b} \\
11.1 \mathrm{a}\end{array}$ & $\begin{array}{r}14.1 \mathrm{a} \\
3.2 \mathrm{~b} \\
4.5 \mathrm{~b}\end{array}$ & $\begin{array}{r}20.9 \mathrm{a} \\
4.3 \mathrm{~b} \\
8.9 \mathrm{~b}\end{array}$ & $\begin{array}{r}30.9 \mathrm{a} \\
2.3 \mathrm{~b} \\
6.8 \mathrm{~b}\end{array}$ & $\begin{array}{l}23.4 a \\
17.6 a \\
14.3 a\end{array}$ & $\begin{array}{c}18.5 a \\
8.4 a b \\
4.1 b\end{array}$ & $\begin{array}{l}8.8 \mathrm{a} \\
4.7 \mathrm{a} \\
9.0 \mathrm{a}\end{array}$ & $\begin{array}{r}11.2 \mathrm{a} \\
4.0 \mathrm{~b} \\
2.6 \mathrm{~b}\end{array}$ \\
\hline Arealleaf $\left(\mathrm{cm}^{2}\right)$ & $\begin{array}{l}1985-86 \\
1986-87 \\
1989-90\end{array}$ & $\begin{array}{l}1.43 a \\
1.32 a \\
1.00 a\end{array}$ & $\begin{array}{l}2.10 \mathrm{a} \\
1.40 \mathrm{a} \\
1.47 \mathrm{a}\end{array}$ & $\begin{array}{l}2.84 a \\
2.49 a b \\
1.88 b\end{array}$ & $\begin{array}{l}5.17 \mathrm{a} \\
3.32 \mathrm{ab} \\
2.39 \mathrm{~b}\end{array}$ & $\begin{array}{l}0.73 a \\
0.49 a \\
0.55 a\end{array}$ & $\begin{array}{l}0.99 a \\
0.71 a \\
0.86 a\end{array}$ & $\begin{array}{l}1.19 a \\
0.73 a \\
0.80 a\end{array}$ & $\begin{array}{l}1.83 a \\
0.85 b \\
0.93 b\end{array}$ \\
\hline Stolon thickness $(\mathrm{g} / \mathrm{m})$ & $\begin{array}{l}1985-86 \\
1986-87 \\
1989-90\end{array}$ & $\begin{array}{l}0.51 a \\
0.54 a \\
0.48 a\end{array}$ & $\begin{array}{l}0.68 \mathrm{a} \\
0.61 \mathrm{ab} \\
0.55 \mathrm{~b}\end{array}$ & $\begin{array}{l}0.82 a \\
0.68 b \\
0.56 b\end{array}$ & $\begin{array}{l}0.96 a \\
0.75 a b \\
0.55 b\end{array}$ & $\begin{array}{l}0.51 \mathrm{a} \\
0.43 \mathrm{a} \\
0.40 \mathrm{a}\end{array}$ & $\begin{array}{l}0.62 a \\
0.53 a \\
0.46 a\end{array}$ & $\begin{array}{l}0.69 a \\
0.54 a b \\
0.44 b\end{array}$ & $\begin{array}{l}0.68 \mathrm{a} \\
0.54 \mathrm{ab} \\
0.42 \mathrm{~b}\end{array}$ \\
\hline
\end{tabular}

* Values with different letters are significantly different $(P<0.05)$ between years within cultivars.

significant reduction in mean area/leaf in the largeleaved cultivar Kopu under rotational grazing in year 5, suggested large-leaved genotypes had been lost (Table 1). However, this trend was also apparent under set stocking, and was reinforced by a significant decrease in stolon thickness in both grazing managements, and indicated that changes in the genetic structure was occurring in all populations (Figure 2).

Figure 2: Change in mean area/leaf and cyanogenesis rating in four white clover populations between sowing (open symbols) and after 4 years (closed symbols) under rotational grazing $(\mathrm{R})$ and set stocking $(\mathrm{S})$.

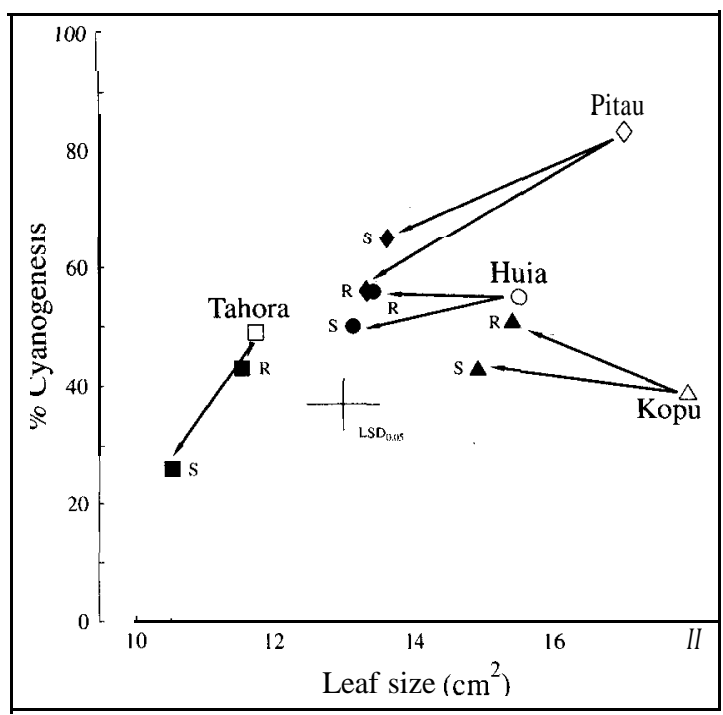

Comparison of the surviving populations sampled in year 4 (spring 1989, and grown for one year in the absence of grazing management influences) with the original population sown (established from seed), also showed that a reduction in leaf size had occurred in all populations except those of Tahora, regardless of grazing management history (Figure 2). Pitau was most affected, being reduced from a leaf size similar to Kopu at sowing, to one similar to Huia. Results for the proportion cyanogenic genotypes in the populations were inconclusive. The general perception is that cyanogenesis is characteristic of white clover populations from warm (dry) climates (Daday 1958) and is associated with increased drought persistency (Caradus \& Williams 1989). With the only significant changes being reductions (Pitau under both grazing managements, and set stocked Tahora), it would appear that drought was not involved in the general reduction in mean area/leaf of all populations.

Closer examination of Figure 1 shows the initial decline in white clover performance appears to have started in summer 18 months after sowing, well before the severe drought in the following late spring-early summer. It is possible that these changes in performance potential are associated with the normal development of white clover populations establishing from seed. Seedlings initially consist of a radiating stolon network dependent upon a large, seminal (tap) root. Sometime after the stolon system establishes nodal rooting systems, the seminal root dies and the plant fragments into several smaller units (Hollowell 1966). The point at which the population in general changes from dependency on seminal roots to adventitious roots, may coincide with a change (loss) in performance of the population. For example, Caradus \& Williams (1989) have found that under field screening conditions, the relative performance of white clover selections during the first year, often declines in subsequent years, and may not reflect their initial performance. Other factors which may impact around this time could be the build up of pathogens and pests following cultivation, and the increase in competition from established grasses. 


\section{Acknowledgements}

The assistance of the following personnel of AgResearch, Palmerston North is appreciated. J. MacKay with sowing, establishment and management of the field experiment; Y. Gray, C. Van Meer and M Greig of the Herbage Laboratory with field sampling and dissection of pasture cores; R. Stretch, C. Youngs and J. Tilbrook with collection and maintenance of genotypes from the field populations, and cyanogenesis and leaf width measurements.

\section{References}

Brock, J.L. 1988. Evaluation of New Zealand bred white clover cultivars under rotational grazing and set stocking with sheep. Proceedings of the New Zealand Grassland Association 49: 203-206.

Brock, J.L.; Hay, M.J.M.; Thomas, V.J.; Sedcole, J.R. 1988. Morphology of white clover (Trifolium repens L.) plants in pastures under intensive sheep grazing.
Journal of Agricultural Science, Cambridge, 111: 273-283.

Brock, J.L.; Hay, R.J.M. 1993. An ecological approach to forage management. Proceedings International Grassland Congress 17: 837-842.

Brock, J.L.; Moon Chul Kim. 1994. Influence of the stolon/soil surface interface and plant morphology on the survival of white clover during severe drought stress. Proceedings of the New Zealand Grassland Association 56: 87-191.

Caradus, J.R.; Williams, W.M. 1989. Breeding for legume persistence in New Zealand. pp. 523-539. In: Marten, G.C. et al. (eds). Persistence of forage legumes. Proceedings of a tri-lateral workshop, Honolulu, Hawaii.

Daday, H. 1958. Gene frequencies in wild populations of Trifolium repens L. III. World distribution. Heredity 12: 169-184.

Hollowell, E.A. 1966. White clover Trifolium repens L., annual or perennial? Proceedings International Grassland Congress 10: 184-187. 